\title{
Creative Industries in the Context of Globalization: Development Processes and Strategic Solutions
}

\author{
Valerija Kontrimiene ${ }^{1}$, Borisas Melnikas ${ }^{2}$ \\ ${ }^{I}$ Faculty of Creative Industries, Vilnius Gediminas Technical University, \\ Vilnius, Lithuania \\ ${ }^{2}$ Faculty of Business Management, Vilnius Gediminas Technical University, \\ Vilnius, Lithuania \\ E-mails: ${ }^{1}$ valerija.kontrimiene@vgtu.lt (corresponding author); ${ }^{2}$ borisas.melnikas@vgtu.lt
}

Received 11 February 2017; accepted 07 April 2017

\begin{abstract}
The object of this paper is related to the sector of creative industries and its development under conditions of globalization. The article analyses a concept of the creative industries thus emphasizing the importance of the sector in the contemporary society and economic development. Particular attention is shifted on the growth of exports and imports of creative industries considering the current challenges of globalization. The main aim of the research is to mark the role and the place of the sector of creative industries in the economy of the modern world, including the tendencies indicating changes in the export and imports of the products created in this sector. The methods of comparative and structural analyses of exports and imports of creative industries have been applied for the research presented in this paper. The research also reveals the impact of the development of the sector of creative industries on employment and economic growth in general, reflecting a need for elaboration of specific strategic solutions in the field of creative industries. The interferences presented in this paper prove that research on the development processes of the creative industry sector, particularly in the context of globalization challenges, is a highly promising trend of scientific knowledge and further research.
\end{abstract}

Keywords: creative industries, globalization, developed countries, developing countries, transition economy countries, strategic solutions.

JEL Classification: F01, F60, O31, Z10.

Conference topic: Internationalization Processes: Contemporary Challenges.

\section{Introduction}

Context. Under conditions of globalization, numerous changes covering mainly all areas of socio-economic life are taking place worldwide. The occurring changes may involve alterations classified as highly significant and aimed at forming new-type economic activity and sectors of cultural and technological progress, at promoting a rapid growth of similar sectors and at causing an increase in consumption volumes and in the role of the products produced in these sectors. In turn, the sector of creative industries can be mentioned as having crucial importance among the sectors of new-type economic activity, culture and technological progress: this sector in particular representatively characterizes the dynamism of the modern era of globalization and focuses on radical outbursts, tendencies towards innovation and creativity. The sector of creative industries and the processes of its development reflect challenges and innovations inherent in the contemporary public life and become a unique symbol of both new values and aspirations as well as a completely new concept of future prospects. The need of new approaches for the evaluation of the role and the place of the sector of creative industries is caused by:

-absence of one common definition of the creative industries which could help to understand the true extend and effectiveness of the sector;

- dependency of the sector of creative industries on intangible assets: novelty, soft innovation, creativity which are not reflected in accounts;

- complicated access of the sector of creative industries to finance that could support and promote the process of creative industries development at both national and at global levels;

- lack of knowledge and instrument for IPR protection and low level of entrepreneur education among creators acting in the field of creative industries;

(C) 2017 V. Kontrimiené, B. Melnikas. Published by VGTU Press. This is an open-access article distributed under the terms of the Creative Commons Attribution (CC BY 4.0) License, which permits unrestricted use, distribution, and reproduction in any medium, provided the original author and source are credited. 
- complicated access to a pool of information and international markets for single creators, small and micro companies in the sector, reflecting slow process of collaboration and clustering among the actors of the sector of creative industries.

In order to react to the above mentioned problems and challenges, a need for elaboration of specific strategic solutions in the field of creative industries has recently underlined by a number of well-known scholars and policy makers. However, only few scientific studies have been based on the analysis of the changing tendencies of the main economic variables in the sector of creative industries considering the current challenges of globalization.

Topicality. The sector of creative industries noticeably turns into an enormously important part of a modern economy. Creative industries appear among the most dynamic sectors of modern economies playing an increasing role for economic growth and social welfare. As a sector of economy, creative industries can be accepted as an area marking the traditions of long-term historical development and as a brand new field, the progress of which has recently started.

The traditions of long-term historical development reflect the fact that different creative, industrial and serviceproviding activities forming the sector of contemporary creative industries and attributed to this particular area have existed and historically developed for a long time. Some of the above introduced activities were known and stimulated by the oldest civilizations: in this case, further emerging, historically formed and multiply experienced long lasting traditions and trends characteristic of creative industries can be properly examined. On the other hand, a modern sector of creative industries can be seen as a completely new evolving area under the living conditions of contemporary society: creative industries, as a new sector of economy, is characterized and becomes unique by the fact that, under the living conditions of contemporary society, this sector combines creative, industrial and service-providing activities that were not connected to a common unified system within the previous practical activity and did not form a uniformly considered phenomenon of socio-economic development as well as cultural, scientific and technological progress. Thus, it is clear that "creative industries can be defined and explored both as certain wholeness characterized by a broad variety of creative, industrial and service-providing activities typical of historically determined long lasting traditions and trends and as a contemporary formed and an extremely rapidly evolving sector of a modern economy" (Melnikas 2016).

In addition, it should also be noted that both, creative industries as a whole and the sector of creative industries as a part of the modern economy, are specific about new and evident integrity and require fairly deep and broad scientific knowledge and testing. An area crucially important for scientific research on creative industries covers progress in creative industries and further development considering the current challenges of globalization: the evident orientation of the growth and development of creative industries to global markets is one of the most important attributes of the industries. As for research on creative industries, the above introduced circumstance determines the need to primarily focus on investigating the impact of globalization factors on creative industries, their growth and development. At the same time, this factor clarifies the purpose of this publication and the contents of the material provided in the paper.

In view of the fact that the sector of creative industries is going to be a more and more important part of the modern economy, the ability to prepare, propose and implement highly effective and efficient measures for developing and improving this sector is of crucial importance. Sequentially, this requires serious and profound scientific knowledge and research taking into account various fields of the development of creative industries under conditions of globalization.

Scientific problem. It should be noted that a scientific problem that requires serious attention occurs due to the fact that the present practice of developing creative industries does not extensively consider a number of specific circumstances characteristic of creative industries and their growth, no advantage in using knowledge about the patterns typical of the development of creative industries can be observed and the advanced practical experience of developing creative industries accumulated in different economies is not adequately summarized. In general, the available scientific knowledge and research intended for creative industries and their development are clearly insufficient and inadequate for up-to-date needs and challenges: this circumstance also reflects the necessity and relevance of research on creative industries and their development.

Object of the research. The research object is the creative industries development under conditions of globalization and its effectiveness evaluation.

Aim of the research. The publication is aimed at disclosing the main point of creative industries and their development thus highly focusing on the challenges faced under conditions of globalization and on highlighting the role and the place of creative industries in the modern economy. The article presents a detailed research description that mainly focuses on the specificities and regularities of developing the sector of creative industries.

Methodology of the research. Research methodology involves a comparative analysis of different theories and theoretical approaches as well as an economic statistical analysis of the development processes of creative industries.

Scientific novelty. The scientific novelty is observed by the main interferences and results of the research which highlight, identify and describe the tendencies, specificities and regularities of developing creative industries as an exceptionally significant and specific sector of economy, paying particular attention on various circumstances of globalization. 
Practical value. The results of the present research could be used in creation and implementation of specific public support activities which will be relevant to the contemporary economic development needs of the sector of creative industries.

\section{Creative industries and their development in the global context: main theoretical approaches}

Creative industries and their development, including globalization conditions, is a completely new area of both practical activity and scientific knowledge and research. It is clear that this area can be characterized by a variety of identified and investigated issues as well as by ongoing and upcoming research and practices. An evident point is that the currently existing theoretical approaches to creative industries and their development also preserve diversity and focus on different aspects and priorities of developing creative industries. The sector of creative industries has been analyzed in a large number of papers. (Florida 2002; Garnham 2005; Hartley et al. 2013; Hautamäki et al. 2010; Howkins 2001; Melnikas 2016; Lis et al. 2012; Lash, Urry 1994; Pratt 2005; Potts 2011; Flew 2012; Cunningham 2002). A broad variety of scientists and experts working in different fields diversely define creative industries and their development and very differently understand, accept and assess the issues of a growth in creative industries. "Economists, regional development agencies, historians, government policymakers, business strategists, lawyers and educationalists have a different take on the topic, but they all have something to contribute to the analysis. As a result, there are important insights scattered across many domains, using different definitions, conceptual frameworks and methodologies for different instrumental purposes' (Hartley et al. 2013). However, as a number of well known researchers in the field of creative industries claim 'creative industries studies now has a robust conceptual toolkit to analyze and solve real problems in cultural life, business strategy, public policy, critical understanding and intellectual advancement alike' (Hartley et al. 2013).

Creative industries, as a concept, emerged not a long time ago, in the late 1990s, as a model of post-industrial development linked to rapid urban reproduction in the UK. However, it seems that there is a contradiction in terms creative industries for the term creative is hardly could be combined with the term industries. According to the definition, being creative means having the skill and ability to produce something new, specially a work of art; showing this ability and involving the use of skill and imagination to produce something new or a work of art. In other words, creativity is a part of human identity, something which most people consider as a part of their nature. Describing the term industry, we deal with the concept from a totally different sphere, such as economy. Thus, industry is the production of goods from raw materials, especially in factories as well as the people and activities involved in producing a particular thing. The question is, how do these two dramatically different areas could be combined and whether do achievements in one sphere contribute to another and vice versa? At this point, the saying "creativity is the power to connect the seemingly unconnected" explains a lot. Going back to the formal origins of the concept of creative industries, it is important to mention the Creative Industries Mapping Document, produced by Department of Culture, Media and Sport (DCMS) which was established by British Labor government. The newly elected British Labor government, headed by Tony Blair, was ready to invest in creativity in 1990s because, as Tony Blair claimed "Our aim must be to create a nation where the creative talents of all the people are used to build a true enterprise economy for the $21^{\text {st }}$ century- where we compete on brains, not on brawn" (Blair 2010). It was the first attempt to identify creative industries, and "as we witness it at present, the term creative industries it was a very successful British export" (Flew 2012). Thus, despite the fact that there is, on the one hand, a contradiction in the term creative industries, on the other hand, the concept of creative industries was increasingly important not only for the UK national prosperity but for all economically advanced and developing countries. The concept of creative industries, first of all, put creativity and culture at the center of British national life in unconventional way, by bringing together arts, media, software and other sectors with more integrated, not fragmental, approaches to cultural policy (Flew 2012). Next, the Creative Industries Mapping Document (CIMD) produced in 1998, underlined the growing economic importance of creative industries, identified as 13 sectors in terms of the main economic variables, such as value added, employment, national income. Besides this, the CIMD played "a critical formative role in establishing an international policy discourse towards a productive engagement with digital technologies, to develop new possibilities for alignment of creativity and intellectual capital with these new engines of economic growth" (Flew 2012). Therefore, one of the main issues of this article is to draw attention to the contribution of the sector of creative industries to exports and job creation in wider economic context, in the context of globalization. The context of globalization was chosen with intention to take the holistic approach to creative sector. In terms of the modern concept of globalization, we consider this process as the fact that different cultural and economic systems around the world are becoming connected and similar to each other. Joshi defines globalization as "the process of integration and convergence of economic, financial, cultural, and political systems across the world brought about by breakthroughs in information and communication technology (ICT) and means of transport and the breaking down of artificial barriers to the flow of goods and services, capital, knowledge, and (to a lesser extent) people across the borders" (Joshi 2014).

Nowadays, the main role in the process of globalization acts new technology and innovation. As Davis and Sigthorsson claim "cultural change, aesthetic change, and technological change are not easily separated; they come along all at once, wrapped up in one another" (Davis, Sigthorsson 2013). At this point, we could speak about syner- 
$g y$, one of the attributes of globalization processes, which is very positive in the sector of creative industries. However, any change brings uncertainty and risk. "Making something new, commercially, is an inherently risky business (...). It is this inherit risk that puts pressure on business in creative industries" (Davis, Sigthorsson 2013). People, in the era of globalization, especially in the field of creative industries, in order to be needed at work, sometimes have to switch sectors; have to be extremely self-confident in trying new ways of working; have not to be afraid of changing place, environment or adapting new skills, and, of course, they should accept existence of tough competition, along with emerging of new, previously not existing jobs. Thus, on the one hand artistic personalities, being a part of creative industries, have to be spontaneous, creative, open to new ideas and risks, flexible and innovative. On the other hand, creative staff could be limited by time, funds, formal rules and other objective restrictions which are essential to manage and control creative process as a part of business. Therefore, it could be claimed, that the expression of duality, as one more important characteristic of globalization, which directly influences the field of creative industries, appears.

In 2008, UNCTAD released Creative Economy Report in which the following concept of creative industries was framed: the creative industries:

- are the cycles of creation, production and distribution of goods and services that use creativity and intellectual capital as primary inputs;

- constitute a set of knowledge-based activities, focused on but not limited to arts, potentially generating revenues from trade and intellectual property rights;

- comprise tangible products and intangible intellectual or artistic services with creative content, economic value and market objectives;

- are at the cross-road among the artisan, services and industrial sectors and constitute a new dynamic sector in world trade.

The UNCTAD model is based on the distribution of all the activities of the creative industries into four main areas: heritage, the arts, media and functional products and identifies creative industries as a number of interconnected sectors that operate across these four areas. UNCTAD has more explicitly championed the role of creative industries as a new engine of economic growth in developing countries (Flew 2012).

From the WIPO perspective, the creative industries may be divided into four groups according to the degree of use of copyright material. The most important are core industries, which are generally regarded as synonymous with copyright industries. The core industries are wholly engaged in the creation, production and manufacturing, performance, broadcast, communication and exhibition, or distribution and sales of protected works. A second group, the interdependent industries, comprises those industries that are engaged in the production, manufacture and sale of equipment whose function is to facilitate the creation, production or use of works and other protected subject matter. A further group, the partial industries, includes those in which a portion of the activities is related to works and other protected subject matter, such as architecture and design. The last category comprises the non-dedicated industries. They include general wholesale and retailing, general transportation, and the Internet (UNCTAD 2008).

Many authors argue that all models of creative industries could be reduced, enlarged or modified, but the essence of the models, above all, proves a very important idea. The idea is, that creativity eventually was publicly recognized as an economic value and the profound importance of creative industries, as a new engine of economic growth and wealth creation, was proved (Howkins 2001). Besides this, bringing together different cultural and creative activities in the era of digital technologies allowed to identify new, mutually reinforcing relationships between different sectors of creative industries which transformed production and distribution platforms for totally new ones and provided opportunity for further scientific research and future interferences.

Moreover, a standardized set of definitions and a common classification system of creative industries are important as a basis for the formation of coherent integrated economic policies that include relations between creativity, culture and international trade policies.

In addition, it should be noted that the development of creative industries, to a large extent, is determined by various factors reflecting innovation processes and synergy manifestations. It is clear that the main idea of creative industries as the development of the economy sector reflects priority orientations towards the generation, dissemination and use of innovations. In turn, the fundamental requirement for innovations and their initiation is the creation of preconditions for synergy: the fact that creative industries cover a wide range of creative activities, including artistic, technical, commercial and other forms of art, shows that this sector is inherently and ingenuously focused on synergy activation and innovation promotion.

Thus, it can be proposed that the specificities and regularities expressing priorities to innovation activity and synergy activation are apparently inherent in creative industries and their development: the latter condition is highly relevant to understanding the importance and viability of the sector of creative industries, including the global environment. 


\section{Research on globalization processes as a priority of scientific knowledge for developing creative industries}

Under globalization conditions, the development of creative industries can be treated as an exceptionally complex area of scientific knowledge and research as well as a field of very important practical activities. Besides, this statement can be interpreted in two ways:

a) taking into account the importance and current issues of the development of creative industries;

b) considering the complexity and multiplicity of globalization processes.

Also, according to a number of scientists, under globalization conditions, a number of specific factors and circumstances the effect of which is particularly significant, are revealed (Lapinskienè et al. 2015; Peleckis 2016). Therefore, the following factors and circumstances can be accepted as having crucial importance:

- factors and circumstances reflecting globally ongoing processes of convergence and standardization, the establishment, spread and application of common and identical norms and standards in all areas of social and economic life in different regions and countries worldwide. Ongoing globalization involves the processes of self/creation, dissemination and implementation of all areas of life encompassing new models of lifestyle, stereotypes of social behaviour, new technological etc. norms and standards, styles, fashions and views on a large international scale and even a global scale, which inevitably results in adequate convergence and unification (however, these processes, within the context of globalization, create preconditions for the global formation of common social, informational, cultural, economic, etc. described spaces);

- factors and circumstances reflecting powerfully ongoing internationalization processes manifesting themselves in all areas, including social and economic life as well as cultural, scientific and technological advancement; these processes determine a number of major different origin changes and actually represent the global processes of social, economic, political development, cultural, scientific and technological advancement and interaction with the environment;

- factors and circumstances reflecting new assumptions and opportunities to initiate and implement the aspirations of synergy and synergetic effects. Under globalization, a number of new opportunities for synergy occur, which determines the links of systems for different cultures and lifestyles, an increasing variety of characteristic areas of activity, the link between new technologies and organizational forms, a range of the previously autonomous and independently from each other functioning organizations as well as mergers and alliances of other operators;

- factors and circumstances reflecting new competitive manifestations and an increasing extent of competition. Under globalization conditions, competition takes new forms on large international and global scales;

- factors and circumstances reflecting a drastic increase in the significance of innovations and innovativeness, creativity, inclinations to uninterruptedly revitalize and widely develop entrepreneurship and new initiatives.

The above-mentioned factors and circumstances of globalization can be characterized by the diversity and multiplicity of their manifestations (Lapinskienè et al. 2015; Peleckis 2016; Lankauskienè 2016; Tvrdikova 2016; YihChang 2016; Melnikas 2016). The factors and circumstances reflecting global ongoing processes of convergence and standardization and the occurrence, spread and application of common and identical norms and standards simultaneously appear as a key feature showing a number of assumptions about a different format of convergence, interaction, integration, collaboration and partnership between different countries and regions, between different social, economic, business, science, humanitarian, etc. areas of activity and between different groups and backgrounds of society on local, regional, international and global scales. This feature mainly describes globally occurring processes of universalization and features the phenomena of forming large spaces of diverse nature.

The factors and circumstances reflecting powerfully ongoing internationalization processes concurrently show that, on the basis of the prevailing certain national cultures and economies, new impact spaces and zones naturally and continuously occur worldwide and thus lead to new international political, economic or other formations able to promote and implement its values and standards as well as to ensure the entrenchment of their power or leadership. Besides, it is evident that such concentrated ongoing internationalization covering different areas of life is to be treated as one of the most important instruments of the globalization itself.

Under globalization conditions, the factors and circumstances reflecting the current assumptions and opportunities to initiate and implement the aspirations of synergy and synergetic effects show the nature and core of advancements, breakthroughs and continuously ongoing improvement processes. The initiation and implementation of synergy and synergetic effects ensures a steady revitalization of quality in all spheres of life, guarantees the promotion of qualitative changes and breakthroughs and assures the stimulation of advanced development. A crucial point is that the initiation and implementation of synergy and synergetic effects offers outstanding opportunities in the globalization context, which determines fundamental changes in the fields of scientific and technological progress, in different areas of social, economic and political life and public culture as well as in society and its structure themselves.

The factors and circumstances reflecting new competitive manifestations and an increasing scope of competition shows that globalization conditions disclose new additional opportunities to promote progress and activate innovative developments and breakthroughs in all areas of life, new threats and risks arising from the growing opposition 
and various contradictions present in the competitive environment. Apparently, the dual (positive and negative) role of competition, in the context of globalization processes, naturally leads to a number of new additional circumstances that may have variable effects on the situation and developmental processes taking place in different areas of social and economic life in various countries and regions.

The factors and circumstances, under globalization conditions, reflecting the significance of an increase in innovation, innovativeness, creativity and inclinations to uninterruptedly revitalize and develop entrepreneurship demonstrate the role of globalization in society and the meaning of the dynamism of its development. It is clear that globalization processes as social, economic, political, technological, etc. changes encourage modifications in the structure of society and the society itself as well as stimulate specific variations in different areas of life. Taking into account that innovation, innovativeness, creativity, revitalization and inclinations significant for entrepreneurship development can be treated as the main precondition for such changes, the specified factors and circumstances characteristic of globalization conditions are admitted to be exceptionally important.

To sum up the above formulated proposals, the importance and role of globalization processes and phenomena can be reaffirmed thus further investigating recent creative industries and processes of developing them.

\section{Creative industries in the context of the contemporary global economic development: main tendencies}

Creative industries appear among the most dynamic sectors of modern economies playing an increasing role for economic growth, social welfare and progress in society. Conpemporary researchers discuss a number of growth accounting metods and models, for the different industries (Lankauskiene 2016; Tvrdikova 2016; Yih-Chang 2016). However, the most important attribute of creative industries which proves an increasing role of creative industries for economic growth in general, considering the current challenges of globalization, is the dynamic growth of exports of creative goods and services.

Under globalization conditions, an increasing role of the sector of creative industries is visibly reflected in the material of economic statistical surveys of the trends in the development of creative industries (DCMS 2001, 2006; 2015a, 2015b; UNESCO 2009, 2010; UNCTAD 2010). With reference to the data suggested by various international organizations, different statistical tables can be compiled, which allows analyzing and comparing the dynamics of the export and import of the sector of creative industries on a global scale or taking into account different regions of the world, different countries or groups of countries. Appropriate data and comments, with particular attention on the common trend reflecting the fact that in both, developed and developing countries, the growth rates of exports of creative goods and services are higher than the growth rates of total exports, can be found in the publication by V. Kontrimiene (Kontrimienè 2016). Moreover, the proportion of exports of creative goods to total exports of goods is substantial, especially in developing countries. According to the figures published in Creative Economy Report 2013, developed countries demonstrate considerably small increase in exports of creative products comparing to developing countries and transition economy countries.

The newest statistical data on exports of creative goods, during the period from 2012 to 2015 , reveal that the situation changed dramatically. The world exports of creative goods decreased by 2 percent. Exports of developed countries rose by 8 percent, whereas exports of developing countries fell by 9.5 percent. Transition economies accounted for 14 percent of the exports decrease. The developing countries displayed a worrying tendency for exports to decrease, whereas the developed countries showed a growing tendency for exports to grow with focus on increasing of visual arts exports: from \$US24billion in 2012 to \$US42billion in 2015. The exports of new media and design of developed countries grew as well during this period. The developing countries and transition economies, on the contrary, demonstrated a decrease in almost all areas of creative goods exports (see Table 1).

Table 1. Exports of creative goods by economic group, 2012 and 2015 (\$US million) (Source: UNCTAD 2017)

\begin{tabular}{l|c|c|c|c|c|c|c|c}
\hline & \multicolumn{2}{|c|}{ World } & \multicolumn{2}{c|}{ Developed countries } & \multicolumn{2}{c}{ Developing countries } & \multicolumn{2}{c}{ Transition economy } \\
\cline { 2 - 10 } & 2012 & 2015 & 2012 & 2015 & 2012 & 2015 & 2012 & 2015 \\
\hline Total: All Creative Goods & 519893 & 509752 & 223594 & 241624 & 292752 & 265080 & 3546 & 3047 \\
\hline Art Crafts & 36405 & 35719 & 9879 & 9450 & 26339 & 26133 & 186 & 135 \\
\hline Audio Visuals & 30694 & 21875 & 19632 & 14880 & 10900 & 6859 & 161 & 135 \\
\hline Design & 326597 & 318216 & 120584 & 130860 & 204086 & 185769 & 1927 & 1586 \\
\hline New Media & 41563 & 42193 & 15639 & 15744 & 25846 & 26371 & 77 & 78 \\
\hline Performing Arts & 5253 & 4386 & 2721 & 2559 & 2526 & 1824 & 5 & 3 \\
\hline Publishing & 40147 & 33660 & 30569 & 25650 & 8442 & 6990 & 1135 & 1020 \\
\hline Visual Arts & 39231 & 53699 & 24567 & 42478 & 14610 & 11132 & 53 & 89 \\
\hline
\end{tabular}



and strategic solutions

Considering the previous period, world growth rates of creative goods exports and imports from 2007 to 2011 years, the growth rates of exports and imports were quite significant and accounted for 3.71 percent and 0.58 percent respectively. (UNCTAD 2013) Analysis of the world growth rates of creative goods exports and imports during 2012-2015 years reveals that the growth rates of exports and imports dropped dramatically and accounted only for 0,23 percent and -0.15 percent respectively. The growth rates of creative goods exports and imports of developing countries, during the same periods, were decreasing at an alarming rate: from 9.33 to -1.89 , and from 5.35 to -8.17 respectively. On the contrary, the developed countries, according to the data, showed significant growth rates during the latest period. The analysis of the growth rates of creative goods exports and imports of developed countries by sectors reveals that visual arts became the most traded sector of developed countries. The growth rates of visual arts exports and imports improved from -2.71 percent to 19.2 percent and from -2.75 percent to 19.26 percent respectively (see Table 2).

Table 2. Growth rates of creative goods exports (E) and imports (I), annual, 2007-2015 (Source: UNCTAD 2017)

\begin{tabular}{|c|c|c|c|c|c|c|c|c|c|c|c|c|c|c|c|c|}
\hline & \multicolumn{4}{|c|}{ World } & \multicolumn{4}{|c|}{ Developed countries } & \multicolumn{4}{|c|}{ Developing countries } & \multicolumn{4}{|c|}{ Transition economy } \\
\hline & \multicolumn{2}{|c|}{$\begin{array}{l}2007-2011 \\
\text { Growth } \\
\text { rates \% }\end{array}$} & \multicolumn{2}{|c|}{$\begin{array}{l}2012-2015 \\
\text { Growth } \\
\text { rates } \%\end{array}$} & \multicolumn{2}{|c|}{$\begin{array}{l}2007-2011 \\
\text { Growth } \\
\text { rates } \%\end{array}$} & \multicolumn{2}{|c|}{$\begin{array}{l}2012-2015 \\
\text { Growth } \\
\text { rates } \%\end{array}$} & \multicolumn{2}{|c|}{$\begin{array}{c}2007-2011 \\
\text { Growth } \\
\text { rates \% }\end{array}$} & \multicolumn{2}{|c|}{$\begin{array}{l}2012-2015 \\
\text { Growth } \\
\text { rates \% }\end{array}$} & \multicolumn{2}{|c|}{$\begin{array}{l}2007-2011 \\
\text { Growth } \\
\text { rates } \%\end{array}$} & \multicolumn{2}{|c|}{$\begin{array}{c}2012-2015 \\
\text { Growth } \\
\text { rates \% }\end{array}$} \\
\hline & $\mathrm{E}$ & I & $\mathrm{E}$ & I & $\mathrm{E}$ & $\mathrm{I}$ & $\mathrm{E}$ & $\mathrm{I}$ & $\mathrm{E}$ & I & $\mathrm{E}$ & $\mathrm{I}$ & $\mathrm{E}$ & I & $\mathrm{E}$ & I \\
\hline 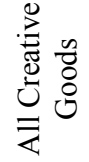 & $\vec{i}$ & $\stackrel{\infty}{n}$ & ָิ & $\stackrel{n}{\tilde{i}}$ & $\exists$ & $\underset{T}{\stackrel{T}{T}}$ & $\begin{array}{l}\infty \\
\infty \\
i\end{array}$ & $\vec{n}$ & $\stackrel{m}{a}$ & $\begin{array}{l}n \\
m \\
n\end{array}$ & $\stackrel{\infty}{\stackrel{\infty}{i}}$ & $\underset{\infty}{0}$ & $\stackrel{t}{\stackrel{\leftrightarrow}{-}}$ & $\begin{array}{l}\sigma \\
\infty\end{array}$ & $\stackrel{\infty}{\overrightarrow{+}}$ & $\begin{array}{l}\stackrel{0}{0} \\
\stackrel{0}{1}\end{array}$ \\
\hline 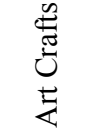 & in & n̂? & त̄ & $\underset{i}{\stackrel{J}{i}}$ & $\stackrel{\substack{T \\
T}}{T}$ & $\underset{i}{\stackrel{+}{i}}$ & $\exists$ & $\vec{i}$ & $\begin{array}{l}\text { n̊ } \\
\text { in }\end{array}$ & 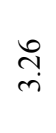 & oे. & $\begin{array}{l}\tilde{\sigma} \\
\infty \\
\infty\end{array}$ & $\stackrel{0}{\stackrel{9}{9}}$ & $\stackrel{\infty}{\stackrel{0}{0}}$ & $\stackrel{\hat{a}}{a}$ & $\underset{\exists}{ت}$ \\
\hline 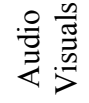 & 1 & 1 & 1 & 1 & 1 & 1 & 1 & 1 & 1 & 1 & 1 & 1 & 1 & I & 1 & I \\
\hline $\begin{array}{l}\frac{5}{50} \\
\bar{D} \\
.\end{array}$ & ๖ి & $\begin{array}{l}t \\
i \\
i\end{array}$ & $\stackrel{?}{\stackrel{\circ}{0}}$ & $\begin{array}{l}\infty \\
\stackrel{\infty}{i} \\
\dot{\varphi}\end{array}$ & $\underset{\mathrm{i}}{\mathrm{i}}$ & $\stackrel{\infty}{\stackrel{\infty}{*}}$ & $\stackrel{\circ}{\stackrel{\circ}{m}}$ & $\underset{\dot{m}}{\stackrel{ \pm}{0}}$ & 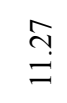 & $\begin{array}{l}\stackrel{n}{n} \\
\text { in }\end{array}$ & $\stackrel{\text { ते }}{i}$ & $\begin{array}{c}\partial \\
\infty \\
\infty\end{array}$ & $\bar{n}$ & $\begin{array}{l}\infty \\
\stackrel{0}{0} \\
\stackrel{-}{-}\end{array}$ & ก̂. & $\begin{array}{l}\infty \\
\stackrel{\infty}{0} \\
\stackrel{0}{1}\end{array}$ \\
\hline$\sum_{z}^{z} \frac{\pi}{z}$ & 1 & 1 & I & 1 & 1 & 1 & 1 & 1 & 1 & 1 & 1 & 1 & 1 & 1 & 1 & I \\
\hline 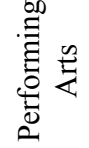 & $\stackrel{n}{n}$ & in & $\begin{array}{l}\infty \\
\stackrel{p}{p} \\
i\end{array}$ & $\begin{array}{l}\vec{b} \\
\dot{p}\end{array}$ & 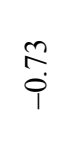 & $\stackrel{0}{\stackrel{7}{T}}$ & 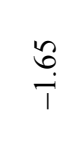 & $\stackrel{\infty}{\stackrel{\infty}{\varphi}}$ & 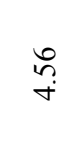 & $\stackrel{+}{m}$ & $\vec{a}$ & $\overrightarrow{\stackrel{i}{i}}$ & $\begin{array}{l}\vec{b} \\
\stackrel{9}{0}\end{array}$ & $\stackrel{n}{n}$ & $\begin{array}{l}0 \\
\dot{n} \\
T\end{array}$ & $\begin{array}{l}0 \\
\stackrel{0}{\infty} \\
\frac{1}{1}\end{array}$ \\
\hline 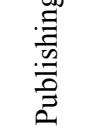 & $\begin{array}{l}\infty \\
\stackrel{i}{i} \\
i\end{array}$ & $\stackrel{f}{\stackrel{f}{i}}$ & $\begin{array}{l}\text { m. } \\
i \\
i\end{array}$ & $\stackrel{\circ}{i}$ & $\stackrel{n}{\stackrel{n}{p}}$ & $\frac{\Delta}{i p}$ & $\overbrace{i}^{m}$ & $\begin{array}{l}\text { ฺ̣ } \\
\text { in }\end{array}$ & $\tilde{n}$ & $\underset{\sim}{\sim}$ & $\begin{array}{l}\text { m. } \\
i p\end{array}$ & $\stackrel{\infty}{\stackrel{\infty}{\uparrow}}$ & 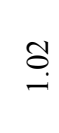 & $\begin{array}{l}\infty \\
\stackrel{\infty}{p} \\
i p\end{array}$ & $\stackrel{\infty}{\vec{p}}$ & $\stackrel{\infty}{\stackrel{0}{1}}$ \\
\hline 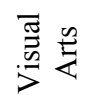 & $\stackrel{\infty}{\circ}$ & în & aे & $\stackrel{+}{\infty}$ & $\vec{i}$ & $\underset{i}{\stackrel{i}{i}}$ & $\stackrel{1}{2}$ & 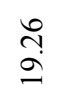 & ઼ָ & 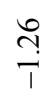 & $\begin{array}{l}\stackrel{a}{0} \\
\text { iे }\end{array}$ & సे & $\overrightarrow{\vec{T}}$ & $\begin{array}{l}\hat{\infty} \\
\infty \\
\dot{n}\end{array}$ & $\begin{array}{l}\tilde{O} \\
\stackrel{\sigma}{0}\end{array}$ & $\vec{n}$ \\
\hline
\end{tabular}

A number of different reasons could explain the situation, but the most sufficient explanations are the following: first, the countries with rapidly growing economy, such as developing and transition economy countries, during the period from 2002 to 2012 were more open to new technologies and innovations, at the same time having low level of IPR protection.

Second, the situation could be also explained by the fact that a large number of firms from developed countries have set up their manufacturing activities in developing countries and transition economy countries as the most competitive locations. Third, the leading position of developing countries in international markets, from 2010 till now, 
suggests that the process of globalization is acting as a strong stimulus to growing consumption of low-value creative goods produced in big amounts by developing and transition economies. Fourth, during the latest period, from 2012 to 2015 , the situation with exports and imports of creative goods changed dramatically: the growth rates of exports and imports of creative goods of developed countries increased significantly, especially in the sector of visual arts, whereas the growth rates of exports and imports of creative goods in developing countries dramatically decreased, especially in the area of art crafts, design and publishing. Fifth, the analysis of the growth rates of creative goods exports and imports of developed countries by sectors reveals that currently, visual arts have become the most traded sector of the developed countries thus underlining the impact of the era of digital technologies and identifying new economic value of creative industries as an engine of contemporary economic growth.

\section{Comparative and structural analyses of creative goods exports}

In order to conduct structural analysis of exports of creative goods as contribution to total exports, there is a need for data on total exports of goods. The Table 4 displays the data on total exports by economic group from 2007 to 2015 years. As it is seen from the data, total world exports of goods in 2014 reached almost US\$19 trillion, but in 2015 there was a significant decrease. Meanwhile, in 2015, total exports volume of developed economies was US\$8trillion, developing economies US\$7trillion and transition economies only US\$525 billion.

It is remarkable that in 2015 there was a sharp decrease in the total export of goods by all economies since the time of the crisis in 2008. Thus, the total world exports from 2014 to 2015 show a decrease of 13 percent, developed countries show a decrease of 12 percent, developing countries report a decrease of 13 percent, transition economies demonstrate a decrease of 31 percent (see Table 3 ).

Table 3. Total Exports of goods, \$US million (Source: UNCTAD 2017)

\begin{tabular}{c|c|c|c|c}
\hline YEAR & World & Developed economies & Developing economies & Transition economies \\
\hline 2007 & 14020775 & 8179913 & 5302110 & 538751 \\
2008 & 16148864 & 9121710 & 6302658 & 724496 \\
2009 & 12555778 & 7082819 & 5006161 & 466798 \\
2010 & 15302138 & 8254560 & 6438434 & 609145 \\
2011 & 18338967 & 9628860 & 7899470 & 810637 \\
2012 & 18497485 & 9445839 & 8228992 & 822654 \\
2013 & 18949351 & 9707259 & 8434017 & 808075 \\
2014 & 18996581 & 9754594 & 8477574 & 764413 \\
2015 & 16551591 & 8614541 & 7411099 & 525951 \\
\hline
\end{tabular}

The data on exports of creative goods, during the same period, is presented in Table 4. World exports of creative goods in 2015 were US $\$ 509$ billion. The analysis of creative goods exports during the latest period, from 2014 to 2015, shows the similar tendency as analysis of total exports of goods with the exception of the situation in developed countries. Thus, the world exports of creative goods from 2014 to 2015 show a decrease of 12 percent, developing countries show a decrease of 20 percent, transition economies reported a decrease of 30 percent, whereas developed countries demonstrate an increase of 0.2 percent. Based on the recent data, two important conclusions have to be made. First, the latest data on total exports of goods and exports of creative goods reveal the fact that there is a significant decrease in both, total exports of goods in all economies and exports of creative goods in developing and transition economies. Second, developed countries, despite the decrease in total exports by 12 percent from 2014 to 2015 , demonstrate an increase of exports of creative goods by 0.2 percent during the same period.

Table 4. Exports of creative goods, \$US million (Source: UNCTAD 2017)

\begin{tabular}{c|c|c|c|c}
\hline YEAR & World & Developed economies & Developing economies & Transition economies \\
\hline 2007 & 400620 & 226978 & 170894 & 2747 \\
2008 & 439172 & 242910 & 192934 & 3327 \\
2009 & 377284 & 194258 & 180399 & 2627 \\
2010 & 419766 & 207027 & 210077 & 2660 \\
2011 & 491535 & 232532 & 255766 & 3236 \\
2012 & 519893 & 223592 & 292752 & 3546 \\
2013 & 531787 & 229664 & 297885 & 4238 \\
2014 & 577190 & 241279 & 331554 & 4357 \\
2015 & 509752 & 241624 & 265080 & 3047 \\
\hline
\end{tabular}


The structural analysis of creative goods exports to total goods exports shows that, from 2007 to 2015 , the value of world exports of creative goods to total world exports of goods was ranging from 2.86 percent to 3.08 percent with a tendency to slight increase.

The structural analysis of creative goods exports to total goods exports by economic group shows that the value of exports of creative goods to total goods by economies was ranging from 0.58 percent to 3.58 percent in 2015 . The highest contribution of creative goods exports to total goods exports by economy show developing countries, 3.58 percent in 2015 . The lowest contribution of creative goods exports to total goods exports by economy, which is only 0.58 percent, show transition economies (see Table 5).

The structural analysis of creative goods exports by economy to total world exports of creative goods provides more information about the value of creative goods exports by economy of total world exports of creative goods. The Table 6 shows the size of the share of creative goods exports by economic group to total world exports of creative goods. Creative goods exports of developing countries constitute more than half of the total creative goods exports. Developed countries are still behind the developing countries but, as it is seen from the latest period from 2014 to 2015 , there was an increase in the value of creative goods exports from 41.80 percent to 47.40 percent to total world exports of creative goods in developed countries. Whereas developing countries, during the same period, demonstrate a worrying decrease in value.

Table 5. Creative goods \% of total goods (Exports) (Source: Author's calculations)

\begin{tabular}{l|c|c|c|c|c|c|c|c|c}
\hline \multicolumn{1}{c|}{ YEAR } & 2007 & 2008 & 2009 & 2010 & 2011 & 2012 & 2013 & 2014 & 2015 \\
\hline World & 2.86 & 2.72 & 3.00 & 2.74 & 2.68 & 2.81 & 2.81 & 3.04 & 3.08 \\
Developed economies & 2.77 & 2.47 & 2.74 & 2.51 & 2.41 & 2.37 & 2.37 & 2.47 & 2.80 \\
Developing economies & 3.22 & 3.06 & 3.60 & 3.26 & 3.24 & 3.56 & 3.53 & 3.91 & 3.58 \\
Transition economies & 0.51 & 0.46 & 0.56 & 0.44 & 0.40 & 0.43 & 0.52 & 0.57 & 0.58 \\
\hline
\end{tabular}

The reason of the latest change of the share of the exports of creative goods by economic group to total world exports of creative goods lies in their different structure: developed countries have mostly production of highervalue-added creative goods which, in the era of digital technologies and new media, are the most traded goods that transform the creative sector's production and distribution platforms for totally new ones and allow to recognize a new economic value of creative industries as an engine of economic growth.

Table 6. Creative goods \% of total world creative goods (Exports) (Source: Author's calculations)

\begin{tabular}{l|c|c|c|c|c|c|c|c|c}
\hline \multicolumn{1}{c|}{ YEAR } & 2007 & 2008 & 2009 & 2010 & 2011 & 2012 & 2013 & 2014 & 2015 \\
\hline World & 100 & 100 & 100 & 100 & 100 & 100 & 100 & 100 & 100 \\
Developed economies & 56.66 & 51.21 & 51.49 & 49.32 & 47.31 & 43.01 & 43.19 & 41.80 & 47.40 \\
Developing economies & 42.66 & 43.93 & 47.82 & 50.05 & 52.03 & 56.31 & 56.02 & 57.44 & 52.00 \\
Transition economies & 0.69 & 0.76 & 0.70 & 0.63 & 0.66 & 0.68 & 0.80 & 0.75 & 0.60 \\
\hline
\end{tabular}

To sum up, during the analysis of contribution of exports of creative goods to economic growth in general, the following interferences have to be made: first, the world exports of creative goods between 2007 and 2011 years increased by 22 percent. Exports of developing countries grew by 50 percent during the same period which put the developing countries in the leading position among different economies with rapidly growing exports in the area of art crafts, design, visual arts and others. Second, the world exports of creative goods between 2012 and 2015 decreased by 2 percent. The developing countries displayed a worrying tendency for exports to decrease significantly during this time, whereas the developed countries showed a growing tendency for exports to grow with focus on increasing of visual arts, new media and design exports. Third, analysis of the world growth rates of creative goods exports and imports during 2012-2015 years reveals that the world growth rates of creative goods exports and imports dropped dramatically and accounted only for 0,23 percent and -0.15 percent respectively. However, the developed countries, in this situation, showed comparatively high growth rates, comparing with the low growth rates during 2007-2011. Fourth, in 2015 there was a sharp decrease in the total export of goods by all economies since the time of the crisis in 2008, the total world exports of goods decreased from US\$19 trillion in 2014 to US\$16.5 trillion in 2015. Fifth, the world exports of creative goods from 2014 to 2015 show a decrease of 12 percent, whereas developed countries demonstrate an increase of 0.2 percent of creative goods exports. Sixth, the structural analysis of creative goods exports to total goods exports by economic group shows that the value of exports of creative goods to total goods by economies was ranging from 0.58 percent to 3.58 percent in 2015 . Seventh, the structural analysis of creative goods exports by economy to total world exports of creative goods reveals that developed countries are still behind the developing countries. However, as it is seen from the latest period, from 2014 to 2015, developing countries demonstrate a worrying decrease in value of exports of creative goods, whereas developed countries show a significant improvement in their exports. 
Overall, developing countries have occupied the leading position in the creative goods exports from 2010 till now. Thus, recently, developing countries play a dominant role in creative industries worldwide. However, the newest statistical data reveal a substantial decrease in creative goods exports produced by developing countries. On the contrary, developed countries demonstrate a rapid increase in their exports of creative goods. The current situation suggests that the new patterns of creative industries production and consumption, which reflect the era of digital technologies and globalization processes, are on the way. Moreover, according to Flew, it is anticipated that "international trade in creative goods and services will continue to grow over the coming years, both as a proportion of total world trade and relative to the growth in creative industries production and consumption overall" (Flew 2012). As a number of reasons for this statement, Flew proposes globalization, as a stimulus for new forms of production and consumption of visual arts, new media, audio visuals and design as "the Internet makes it easier to access an intangible format through digital downloads" (Flew 2012).

\section{Conclusions}

The processes of creative industries and their development are an exceptionally important and promising area of practical business and economic activity as well as research. The significance of the field is particularly notable in the context of contemporary globalization challenges.

Sector of creative industries is now recognized as the most important and dynamic sector in the contemporary economy. The most important attributes of the sector of creative industries are the following: first, creative industries can be defined and explored both as a broad variety of creative activities of historically determined long lasting traditions and as a contemporary formed sector of a modern economy. Second, there is no agreement on one common definition of creative industries: different definitions of creative industries have a different understanding on what creative industries are and what content should be included in the sector of creative industries. Third, the era of digital technologies identified new, mutually reinforcing relationships between different sectors of creative industries which transformed production and distribution platforms for totally new ones and allowed to recognize an economic value of creative industries as an engine of economic growth and wealth creation. Fourth, one common definition of the sector of creative industries is needed for the formation of coherent international trade policy and further scientific research.

The progress in creative industries and the further development of the sector of creative industries influence the current challenges of globalization. Under globalization conditions, the development of creative industries is characterized by a number of specificities and regularities among which particularly distinctive features and patterns reflect, first of all, priorities of creative activity and creativity; second, the complexity of creative activity and creativity expressed through the inclinations and strengths of artistic, scientific, technical, commercial, etc. creativity in different areas; third, the continuous stimulation of different types of synergies and initiation of innovations take place; fourth, plenty of new opportunities for making the self-fulfilment process of creative people more activate are offered; fifth, new opportunities for economic growth and international cooperation are opened up.

The most important attribute of creative industries which proves an increasing role of creative industries for economic growth worldwide is the dynamic growth of exports of creative goods and services. The tendencies indicating changes in exports of the goods produced in the sector of creative industries reveal the following phenomena: developing countries outran developed countries and accounted for 50 percent of total exports of creative goods in 2010. The changing situation in international creative industries markets suggests that developing countries recently play a dominant role in creative industries worldwide. However, the current statistical data disclose a substantial decrease in creative goods exports produced by developing countries. Alternatively, developed countries demonstrate an apparent increase in exports of creative goods. In this context, it s important to highlight that the process of globalization acts as a strong stimulus to new forms of growing consumption in the era of digital technologies.

Besides this, creative industries role needs to be seen as a driving force of new job generation. However, this is a case when a substantial contribution of creative industries to total employment show developed countries, whereas developing countries such as China accounts only for 2 per cent of total employment. The situation could be explained by the different structure of cultural creative sector in different economies. Developed countries have mostly production of higher-value-added creative goods and services, which is highly labor-intensive. Developing countries, on the contrary, produce vast of mass, low-value-added manufactured goods, such as toys or cheap imitation jewelry.

As it is generally accepted by a number of scientists, economists, historians, government policymakers, business strategists, educationalists and was determined by the present research, the sector of creative industries nowadays is recognized as a leading sector in generating international trade, economic growth, employment and social welfare worldwide. Moreover, it is anticipated and is proved by the present research, that from the economic perspective, creative industries will be proceed to grow at a faster pace than the rest of economy. Therefore, the sector of creative industries is a niche field for further scientific studies being central to debates about development of the $21^{\text {st }}$ century economy, culture and policy.

To sum up, the need and relevance of further research on the development of creative industries can be emphasized. 


\section{References}

Blair, T. 2010. Foreword. In National Advisory Committee on creative and cultural education, all our futures: creativity, culture and education. report to the secretary of state for education and employment, and the secretary of state culture, media and sport [online], [cited 15 June 2016]. Available from Internet: www.cypni.org.uk/downloads/alloutfutures.pdf

Cunningham, S. 2002. From cultural to creative industries: theory, industry and policy implications. Media International. Australia. $102 \mathrm{p}$.

Davis, R.; Sigthorsson, G. 2013. Creative industries: from theory to practice. Sage. 245 p.

DCMS. 2001. Creative industries mapping document [online], 2 ed. [cited 18 June 2016]. Available from Internet: https://www.gov.uk/government/publications/creative-industries-mapping-documents-2001

DCMS. 2006. Creative industries statistical estimates statistical bulletin [online], [cited 10 July 2016]. Available from Internet: https:/www.gov.uk/government/uploads/system/uploads/attachment_data/file/78107/CreativeIndustriesEconomicEstimates 2007.pdf

DCMS. 2015a. Creative industries economic estimates [online], [cited 10 July 2016]. Available from Internet: https://www.gov.uk/government/statistics/creative-industries-economic-estimates-january-2015

DCMS. 2015b. Creative industries: focus on employment [online], [cited 21 July 2016]. Available from Internet: https://www.gov.uk/government/uploads/system/uploads/attachment_data/file/439714/Annex_C__Creative_Industries_Focus_on_Employment_2015.pdf

Flew, T. 2012. The creative industries culture and policy. Sage. 232 p. https://doi.org/10.4135/9781446288412

Florida, R. 2002. Creative city [online], [cited 10 July 2016]. Available from Internet: http://www.creativeclass.com/richard_florida

Garnham, N. 2005. From cultural to creative industries: an analysis of the implications of the 'creative industries' approach to arts and media policy making in the United Kingdom, International Journal of Cultural Policy 11(1): 15-29. https://doi.org/10.1080/10286630500067606

Hartley, J.; Potts, J.; Cunningham, S.; Flew, T.; Keane, M.; Banks, J. 2013. Key Concepts in Creative Industries. Sage. 160 p.

Hautamäki, A.; Turkki, T.; Brandenburg, C.; Areblad, C. 2010. Creative economy and culture in the innovation policy. Publications of the Ministry of Education, Finland [online], [cited 18 June 2016]. Available from Internet: http://www.minedu.fi/export/sites/default/OPM/Julkaisut/2010/liitteet/OPM13.pdf

Howkins, J. 2001. The creative economy: how people make money from ideas. Penguin. $156 \mathrm{p}$.

Joshi, R. 2014. International marketing. Oxford University Press. 254 p.

Kontrimienè, V. 2016. Creative industries in the contemporary economy: globalization processes, Viešasis administravimas $\mathrm{Nr} 3-$ 4: $38-46$.

Lankauskienè, T. 2016. Application of the growth accounting method for the construction industry, Journal of Business Economics and Management 17(3): 430-443. https://doi.org/10.3846/16111699.2016.1173580

Lapinskienė, G.; Peleckis, K.; Radavičius, M. 2015. Economic development and greenhouse gas emissions in the European Union countries, Journal of Business Economics and Management 16(6): 1109-1123. https://doi.org/10.3846/16111699.2015.1112830

Lash, S.; Urry, J. 1994. Economies of signs and space. Sage. 189 p.

Lis, B.; Niestedt, H.; Proner, P.; Yalazi; G. Mauch, A. 2012. SMEs going global: a comparison of the internationalization strategies of publishers and online social networks [online], International Rewie of Management and Marketing [cited 18 June 2016]. Available from Internet: www.enjournals.com

Melnikas, B. 2016. Šiuolaikinès visuomenès intelektinis potencialas: aukštosios technologijos, tinklaveika bei kūrybiniu industriju plètra. Viešasis administravimas. Vilnius: Lietuvos viešojo administravimo lavinimo institucijų asociacija. Nr. 1(49)-2(50): 29-41.

Peleckis, K. 2016. International business negotiation strategies based on bargaining power assessment: the case of attracting investments, Journal of Business Economics and Management 17(6): 882-900. https://doi.org/10.3846/16111699.2016.1233511

Potts, J. 2011. Creative Industries and Economic evolution. Edvard Elgar publishing. 199 p.

Pratt, A. 2005. Cultural industries and public policy, International Journal of Cultural policy 11(1): 31-44. https://doi.org/10.1080/10286630500067739

Tvrdikova, M. 2016. Increasing the business potential of companies by ensuring continuity of the development of their information systems by current information technologies, Journal of Business Economics and Management 17(3): 475-489. https://doi.org/10.3846/16111699.2013.839475

UNCTAD. 2008. Creative economy report [online], [cited 8 September 2016]. Available from Internet: http://unctad.org/en/docs/ditc20082cer_en.pdf

UNCTAD. 2010. Creative economy report [online], [cited 23 September 2016]. Available from Internet: http://unctad.org/en/Docs/ditctab20103_en.pdf

UNCTAD. 2013. Creative economy report [online], [cited 12 September 2016]. Available from Internet: http://www.unesco.org/culture/pdf/creative-economy-report-2013.pdf

UNCTAD. 2017. Statistical date on creative economy [online], [cited 17 September 2016]. Available from Internet: http://unctadstat.unctad.org/wds/ReportFolders/reportFolders.aspx 

and strategic solutions

UNESCO. 2009. creative industries - UNESCO culture [online], [cited 30 May 2009]. Available from Internet: http://www.uis.unesco.org/culture/Documents/framework-cultural-statistics-culture-2009-en.pdf

UNESCO. 2010. Understanding creative industrie: cultural statistics for public policy making [online], [cited 28 September 2016]. Available from Internet: http://portal.unesco.org/culture/en/files/30297/11942616973cultural_stat_EN.pdf/cultural_ stat_EN.pdf

Yih-Chang Qu. 2016 Using a hybrid decision-making model to evaluate the sustainable development performance of high-tech listed companies, Journal of Business Economics and Management 17(3): 331-346.

https://doi.org/10.3846/16111699.2015.1110713 